\title{
Hydroxyapatite Based Materials for Bone Tissue Engineering: A Brief and Comprehensive Introduction
}

\author{
Hui Shi ${ }^{1,2} \mathbb{D}_{\text {, Ziqi Zhou }}{ }^{1,2}$, Wuda Li $^{1,2}$, Yuan Fan ${ }^{1,2}$, Zhihua Li ${ }^{1,2, *}$ and Junchao Wei ${ }^{1,2, *}$ \\ 1 School of Stomatology, Nanchang University, Nanchang 330006, Jiangxi, China; shihui@ncu.edu.cn (H.S.); \\ ziqi0220@163.com (Z.Z.); a13647454900@163.com (W.L.); fanyuan51888@163.com (Y.F.) \\ 2 The Key Laboratory of Oral Biomedicine, Nanchang 330006, Jiangxi, China \\ * Correspondence: lizhihua@ncu.edu.cn (Z.L.); weijunchao@ncu.edu.cn (J.W.)
}

Citation: Shi, H.; Zhou, Z.; Li, W.; Fan, Y.; Li, Z.; Wei, J. Hydroxyapatite Based Materials for Bone Tissue Engineering: A Brief and Comprehensive Introduction. Crystals 2021, 11, 149. https://doi.org/ $10.3390 /$ cryst11020149

Academic Editor: Leonid Kustov Received: 13 December 2020

Accepted: 26 January 2021

Published: 1 February 202

Publisher's Note: MDPI stays neutral with regard to jurisdictional claims in published maps and institutional affiliations.

Copyright: (c) 2021 by the authors. Licensee MDPI, Basel, Switzerland. This article is an open access article distributed under the terms and conditions of the Creative Commons Attribution (CC BY) license (https:// creativecommons.org/licenses/by/ $4.0 /)$.
Abstract: Hydroxyapatite (HA) is widely used in bone tissue engineering for its bioactivity and biocompatibility, and a growing number of researchers are exploring ways to improve the physical properties and biological functions of hydroxyapatite. Up to now, HA has been used as inorganic building blocks for tissue engineering or as nanofillers to blend with polymers, furthermore, various methods such as ion doping or surface modification have been also reported to prepare functionalized HA. In this review, we try to give a brief and comprehensive introduction about HA-based materials, including ion-doped HA, HA/polymer composites and surface modified HA and their applications in bone tissue engineering. In addition, the prospective of HA is also discussed. This review may be helpful for researchers to get a general understanding about the development of hydroxyapatite based materials.

Keywords: hydroxyapatite; polymer composites; surface modification; bone tissue engineering

\section{Introduction}

Bone defects resulting from tumors, trauma or abnormal development frequently require surgical intervention requiring bone grafts. Autografts present important osteogenic characteristics that represent the "gold standard" [1]. However, this method has been associated with various drawbacks, such as donor site morbidity in the way of infection, pain, and hematoma formation. The limited supply of autograft tissue and the potential risks with allografts have inspired surgeons and engineers to explore new methods to repair bone defects. Among all the reported methods, tissue engineering [2], which is a comprehensive application of multidisciplinary methods to improve or replace biological tissues, has provided a new choice for the treatment of bone defects. There are several factors that have critical effects in the process of tissue engineering; the tissue engineering scaffolds are the primary factor in bone tissue engineering [3]. Furthermore, the ideal materials used for bone tissue engineering should have good bone conductivity and inductivity properties [4,5].

Hydroxyapatite $\left(\mathrm{Ca}_{10}\left(\mathrm{PO}_{4}\right)_{6}(\mathrm{OH})_{2}, \mathrm{HA}\right)$, as one of the main components of natural bone, can increase the concentration of local $\mathrm{Ca}^{2+}$, which can activate the proliferation of osteoblasts and promote the growth and differentiation of mesenchymal stem cells (MSC) [6]. Due to its non-immunogenic properties, biocompatibility, bioactivity and good bone conductivity, HA has been widely used in bone repair [7-10]. Up to now, various types of HA-based materials such as pure HA, ion-doped HA, and HA/polymer composites, have been designed and investigated, however, some disadvantages of hydroxyapatite, such as brittleness and easy aggregation still exist [11]; therefore, there is still a long way to go to prepare satisfying HA-based materials.

In recent years, many reviews on hydroxyapatite have been published, and most of them focus on the application and preparation of HA [12-15]. Both physicians and 
materials scientists have paid much attention to the investigation and application of HAbased materials. In our opinion, it is a simple and effective method for new researchers to quickly get a whole understanding about HA by reading review works. Thus, in this review, we try to give a brief and comprehensive summary about HA-based materials, which includes ion-doped hydroxyapatite, hydroxyapatite polymer composites and surface modified hydroxyapatite; meanwhile, their applications in bone tissue engineering will also be introduced. Furthermore, the perspective and challenges will also be addressed. This review may be helpful for researchers who are interested in bone tissue engineering to get a quick glance on HA-based materials, and then help them to select the proper materials according to their interest or requirements.

\section{Ion-Doped Hydroxyapatite}

In the crystal structure of hydroxyapatite, the $\mathrm{Ca}^{2+}, \mathrm{PO}_{4}{ }^{3-}$ and $\mathrm{OH}^{-}$can be replaced by other ions $[12,16] . \mathrm{OH}^{-}$is easily replaced by a small amount of $\mathrm{F}^{-}$and $\mathrm{CO}_{3}{ }^{2-} ; \mathrm{Ca}^{2+}$ can be easily replaced by $\mathrm{Sr}^{2+}, \mathrm{Mg}^{2+}$ and $\mathrm{Zn}^{2+}$; and $\mathrm{PO}_{4}{ }^{3-}$ can be replaced by $\mathrm{CO}_{3}{ }^{2-}$ and $\mathrm{SiO}_{4}{ }^{4-}$ and thus ion doped hydroxyapatite is formed (Figure 1) [12]. The existence of these ions may affect the crystallization, mechanical properties, degradation and biological activity of apatite, and then affect the physiological function of hard tissue in the organism [12,17-20]. In order to obtain biomimetic materials which are similar to the natural apatite in composition, structure and function, ion doped hydroxyapatite has been extensively investigated.
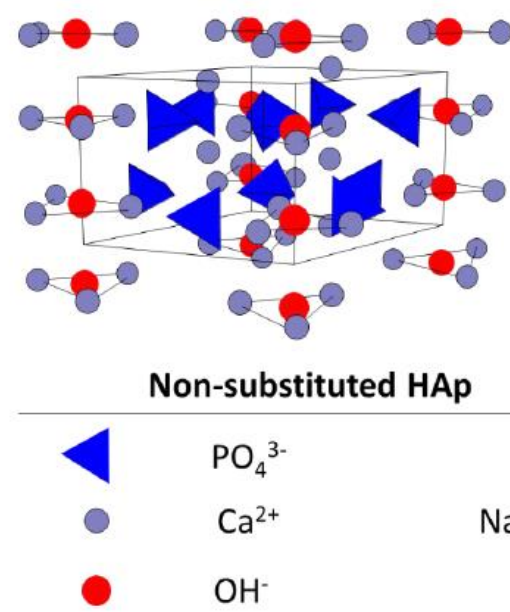

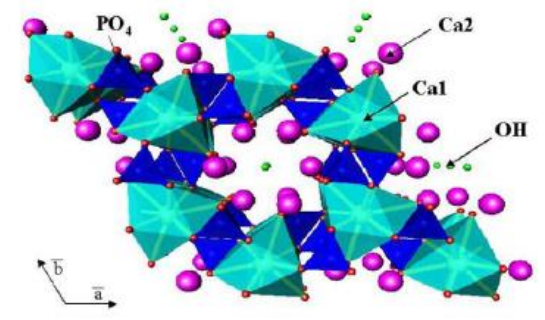

Substituted HAp

$$
\begin{gathered}
\mathrm{SiO}_{4}{ }^{4-}, \mathrm{CO}_{3}{ }^{2-}, \mathrm{SeO}_{3}{ }^{2-} \\
\mathrm{Na}^{+}, \mathrm{Zn}^{2+}, \mathrm{Sr}^{2+}, \mathrm{Mg}^{2+}, \mathrm{Ag}^{+}, \mathrm{Cu}^{2+}, \mathrm{Co}^{2+}, \mathrm{Mn}^{2+} \\
\mathrm{F}^{-}, \mathrm{CO}_{3}{ }^{2-}
\end{gathered}
$$

Figure 1. The $\mathrm{Ca}^{2+}, \mathrm{PO}_{4}{ }^{3-}$ and $\mathrm{OH}^{-}$in the crystal structure of hydroxyapatite can be substituted by many other ions [12].

\subsection{Strontium Doped Hydroxyapatite (Sr-HA)}

Strontium is one of the essential trace elements in the human body; it was noticed that strontium in the human body had the same physiological pathway as calcium, and preferentially deposited in bone and teeth [21]. Low dose strontium can inhibit osteoclast activity, reduce bone absorption, promote osteoblast proliferation and promote bone formation [22-24]. When $\mathrm{Sr}^{2+}$ is incorporated into the $\mathrm{HA}$ lattice, $\mathrm{Sr}^{2+}$ replaces $\mathrm{Ca}^{2+}$ and forms

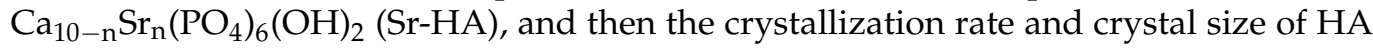
decreases, and the lattice constant changes [25].

The mechanical properties of HA can be improved by doping of Sr into HA [26-28]. When the molar ratio of $\mathrm{Sr} /(\mathrm{Sr}+\mathrm{Ca})$ is $5 \%$, the compressive strength of Sr-HA can be improved to $66.57 \mathrm{MPa}$, which matches the value of human bones, and is expected to apply in clinical applications [26]. In addition, Sr-HA has attractive biocompatibility. HA nanoparticles with higher Sr loading can promote osteosarcoma cell proliferation, while 
the cell morphology remains nearly the same [27]. When Sr-HA was used as a coating on titanium, the Sr-HA enhanced cell attachment much better than the HA coating did [28].

Sr-HA promotes osteogenic differentiation by activating the Wnt $\beta$-Catenin pathway, especially in osteoporosis [29,30]. After culturing MG63 cells in vitro, it was found that the expressions of osteogenesis related genes (alkaline phosphatase (ALP), runt-related transcription factor 2 (RUNX2), osteopontin (OPN), osterix, osteocalcin (OCN), and collagen I (Col-I)) increased with the extension of the culture time. In the case of HA coating with relatively high strontium content (3-7\%), the positive effect of ions on osteocytes was especially obvious [31-33]. Compared with uncoated titanium implants, Sr-HA coated implants formed osteoid 7 weeks after implantation. 12 weeks after implantation, osteoid new bone formed on the HA implant, while Sr-HA began to mineralize. After 16 weeks of implantation, the bone on the Sr-HA was completely mineralized [30]. In vivo studies confirmed that after implantation of the Sr-HA scaffold in the bone defect area, extracellular matrix accumulated, and histology and computed tomography scanning showed significant enhancement of bone formation and an increase in mature and remodeled bone [34].

Strontium was shown to inhibit the activity of osteoclasts; Sr-HA may evoke a specific cellular response, thus exhibiting promising characteristics to assist in new bone formation, especially if bone turnover is impaired as a result of metabolic diseases such as osteoporosis. Strontium ranelate has been used in the treatment of osteoporosis [35].

\subsection{Zinc Doped Hydroxyapatite ( $\mathrm{Zn}-H A)$}

$\mathrm{Zn}$ mainly exists in bone in vivo and is closely related to bone metabolism. It stimulates bone development and mineralization, promotes osteoblast proliferation and osteocalcin production, accelerates bone matrix maturation and inhibits osteoclast activity [36-38]. When Zinc is doped into HA, it will endow many functions to HA. Zn-HA can show excellent bioactivity, osteogenesis ability, anti-inflammatory effect and antibacterial ability [39-41]. Thus, Zn-HA has been widely investigated and applied.

$\mathrm{Zn}-\mathrm{HA}$ has good bioactivity. When Zn-HA was immersed in simulated body fluid (SBF), the apatite layer formed on the surface of the material, and the thickness of the apatite layer became thicker with the increase of Zn content, indicating that $\mathrm{Zn}$ was conducive to mineralization and could improve the bioactivity of HA [42].

$\mathrm{Zn}-\mathrm{HA}$ has a good antibacterial effect; HA doped with less than $1 \%$ of zinc ions has effective antibacterial properties [43]. The maximum inhibitory concentration of $\mathrm{Zn}$ 2\%-HA to Gram-positive bacteria and Gram-negative bacteria was $50 \pm 5 \%$ and $77 \pm 5 \%$, respectively [44]. The antimicrobial effect of $\mathrm{Zn}-\mathrm{HA}$ layer on the growth of candida albicans showed that even after $8 \mathrm{~h}$ of incubation, the growth of fungal cells was inhibited and weakened with time [45]. Therefore, the use of Zn-HA in bone tissue engineering scaffolds has the effect of antibacterial and regulating immune cells, which can increase the value of scaffold materials.

\subsection{Silver Doped Hydroxyapatite ( $A g-H A)$}

Silver is an inorganic antibacterial agent, which interferes with the electron transfer process on the bacterial plasma membrane, and it affects the ATP synthesis in the bacterial cells; additionally, it promotes the production of ROS and causes cell damage. Silverbased antibacterial agents have attracted much attention due to their excellent antibacterial activity $[46,47]$. The radius of $\mathrm{Ag}^{+}$is close to the radius of $\mathrm{Ca}^{2+}$, so silver can replace the calcium in the HA lattice under specific circumstances and forms silver doped HA (Ag-HA), which may improve the clinical and biological application of HA.

Generally, HA itself does not have antibacterial properties. While Ag-HA may have exciting antibacterial properties, however, the silver content may have great affection on its biosafety; low silver content doped hydroxyapatite may have excellent antibacterial activity $[48,49]$. It was demonstrated that both Escherichia coli and Staphylococcus aureus are sensitive to Ag-HA, and thus Ag-HA have been widely used as functional coatings on 
various materials, which resulted in the significantly reduction of bacterial adhesion when exposed to the composite $\mathrm{Ca}_{10-x} \mathrm{Ag}_{x}\left(\mathrm{PO}_{4}\right)_{6}(\mathrm{OH})_{2}$ [50-52]. Briefly, the antibacterial activity of $\mathrm{Ag}$-HA are greatly associated with the ratio of $\mathrm{Ag}$ to $\mathrm{Ca}$; even the $\mathrm{Ag}$ to $\mathrm{Ca}$ ratio was only 0.005, therefore the antibacterial activity of HA can be significantly enhanced [53]. Although a small amount of silver plays an antibacterial role, a large amount of silver may be toxic [54]. Cytotoxicity tests using osteoblasts showed that the samples containing $6.5 \mathrm{wt} \%$ silver had negative effects on the reaction, proliferation and apoptosis of osteoblasts, as well as the production of protein and osteocalcin [51].

\subsection{Silicon Doped Hydroxyapatite (Si-HA)}

Silicon plays an important role in the development of bone and cartilage [55]; the bioactivity and biocompatibility of bioceramics, such as bioglass, calcium silicate and wollastonite, are significantly improved after adding silicon. In addition, silicon has a good ability to promote the adhesion, proliferation and differentiation of bone cells; it can up regulate the gene expression of osteoblasts and increase the osteointegration activity [56].

$\mathrm{Si}-\mathrm{HA}$ has similar structure as $\mathrm{HA}$, while part of $\mathrm{PO}_{4}{ }^{3-}$ is replaced by $\mathrm{SiO}_{4}{ }^{4-}$. SiHA can enhance the formation of crystalline apatite layers in simulated body fluid (SBF), demonstrating its exciting bioactivity $[57,58]$. Si-HA improved the rate and amount of bone apposition over pure HA in vivo. The proliferation rate of osteoblasts on the Si-HA coating was faster than that of HA, and biomineralization with a higher level was observed on the Si-HA samples [59]. Many apatite microspheres were observed near the Si-HA implant after 12 weeks in vivo, and the morphology of these aggregates was rather similar to those observed in mineralized cartilage [60]. The bone growth rate of Si-HA (37.5 $\pm 5.9 \%)$ was significantly higher than that of HA $(22.0 \pm 6.5 \%)$, and the bone/implant coverage of Si-HA (59.8 $\pm 7.3 \%)$ was significantly greater than that of HA (47.1 $\pm 3.6 \%)$ in vivo [61] These results indicated that Si-HA can significantly improve osteogenesis, making Si-HA an attractive alternative to conventional HA materials for bone tissue engineering.

\subsection{Fluorine Doped Hydroxyapatite (F-HA)}

Fluoride is essential for human health, such as neuromodulation and caries prevention and it plays an active role in maintaining bone structure and function [62]. Fluoride can promote the proliferation of osteoblasts and low levels of fluoride can enhance bone formation in vivo [63]. In addition, it inhibits the activation and differentiation of osteoclasts by reducing the expression of matrix metalloproteinase- 9 and tartrate resistant acid phosphatase [64].

F-HA is a kind of doped calcium phosphate with biological activity. Because the a-axis lattice parameters of F-HA are smaller than those of HA, the addition of fluorine can increase the stability of HA and decrease the solubility of HA $[65,66]$. F-HA showed good apatite-like layer deposition ability [67], can promote cell adhesion and protein adsorption, and improved ALP activity in cell culture [68]. It can obviously prevent the decrease of bone mineral density caused by osteoporosis [69,70], and inhibit bacteria growth [71,72].

Compared with HA, F-HA has superior bioactivity. When immersed in SBF for 21 days, there was almost no apatite on the surface of the HA scaffold, while after 7 days of culture, the whole surface of F-HA was covered with a thick phosphorite layer [69], demonstrating that F-HA has excellent bioactivity and may have great potential for bone regeneration. In addition, F-HA has obvious antibacterial activity. Wang et al. blended $40 \mathrm{wt} \%$ nano F-HA and polyetheretherketone (PEEK) powder and prepared F-HA/PEEK composite; the antibacterial test indicated that F-HA/PEEK effectively inhibited the adhesion and proliferation of Streptococcus mutans [73]. When F-HA was coated on the surface of other materials, the F-HA coatings also showed great antibacterial effect to Streptococcus mutans, Escherichia coli and Porphyromonas gingivalis [74]. Some research demonstrated that even a small amount of F-HA can show enough antibacterial activity [28], suggesting their potential in oral and other biomedical applications [73]. 
F-HA can effectively promote osteogenesis and inhibit osteoclast differentiation; the in vivo results of F-HA/PEEK used for bone repair showed direct fusion of bone to FHA/PEEK composite surface, and no inflammation or necrosis was observed. In particular, more bones were found around the F-HA/PEEK implants than around those of the PEEK control (Figure 2) [73]. Kim et al. compared the osteogenesis of F-HA/PCL and HA/PCL composites, and found that F-HA contained materials that could significantly improve the ALP activity and osteocalcin expression of osteoblasts [75]. The material containing F-HA increased the initial adhesion of osteoblasts, promoted cell proliferation and mineralization, and significantly increased the amount of new bone formation in vivo. These findings demonstrated that F-HA might be a promising candidate for bone tissue engineering.
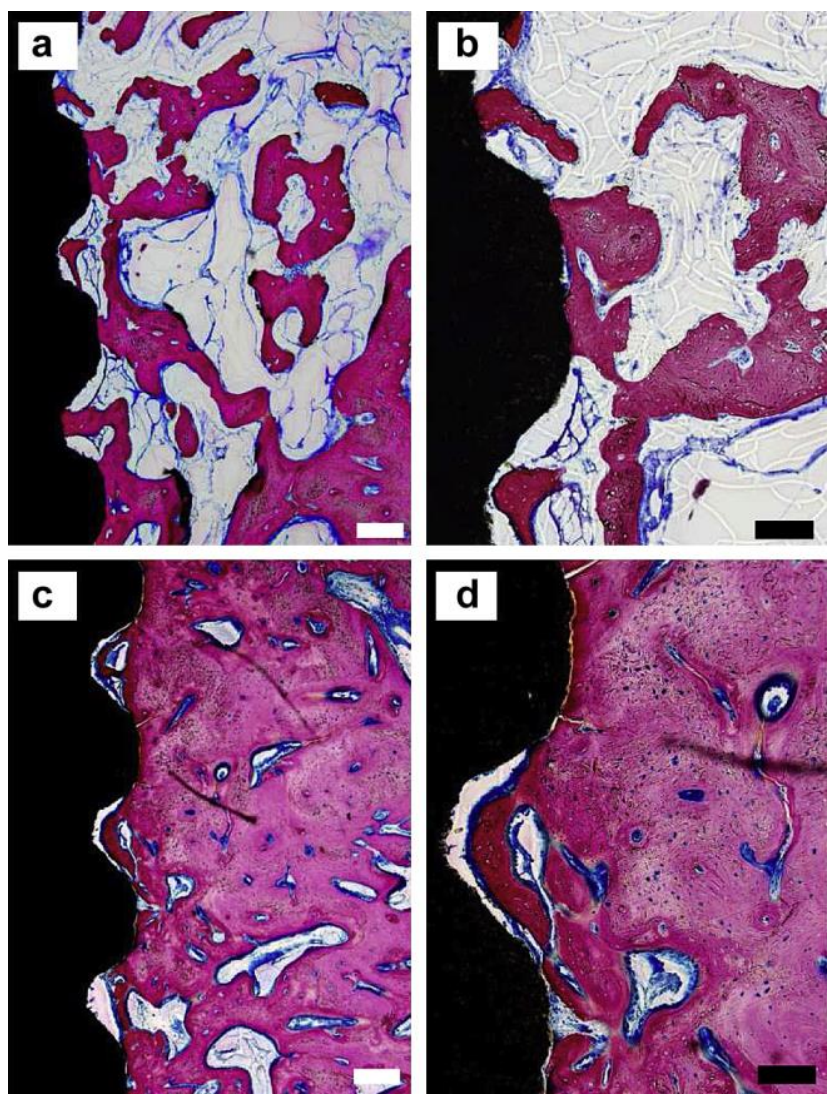

Figure 2. Histological analysis of the tissue response to bare polyetheretherketone (PEEK) (a,b) and fluorine doped hydroxyapatite (F-HA)/PEEK implants (c,d) after 8 weeks. The subfigures (b) and (d) refer to the higher-magnification images of $(\mathbf{a}, \mathbf{c})$. The dark red area represents the newly formed bone, and dark black represents the PEEK-based implant. (white scale bar: $200 \mu \mathrm{m}$, black scale bar: $100 \mu \mathrm{m})$ [73].

\subsection{Other Ion Doped Hydroxyapatite}

There are also many other types of ion doped hydroxyapatites, which can improve the biological properties of HA via ion doping. For example, magnesium doped hydroxyapatite (Mg-HA) promotes new bone formation on the implant material, controls the initial degradation rate and guides bone regeneration [76]. Mg-HA can significantly inhibit Staphylococcus aureus, Pseudomonas aeruginosa and Escherichia coli $[77,78]$. Copper doped hydroxyapatite ( $\mathrm{Cu}-\mathrm{HA})$ showed proper cell proliferation, osteogenic activity [79], and antibacterial properties, resulting in significant reductions of Escherichia coli and Staphylococcus aureus biofilms [80]. Manganese doped hydroxyapatite (Mn-HA) is able to regulate the osteoblast differentiation, control the bone resorption, and promote the cell adhesion and synthesis of extracellular matrix proteins [81]. Cobalt doped hydroxyapatite (Co- 
HA) promotes the neovascularization and the angiogenesis of the newly formed bone tissues [82].

Table 1 summarizes some relevant studies on ion doped hydroxyapatite and its enhanced biological function. The investigation of these ion-doped hydroxyapatites can help us know more about the natural hard tissues' structure and excellent biological activity, and then help us to design novel implant materials with unique structure and performance. However, because of the low bending strength, high brittleness, and easy fracturing, HA and various ion-doped HA can only be used in non-load bearing parts. In addition, the elastic modulus of these inorganic materials are much higher than that of natural bone, and its mechanical properties do not match with human bone, and thus their application in clinical applications were limited [83]. To solve this problem, HA has been combined with various polymers to form various $\mathrm{HA}$ / polymer composites, which have been widely used in bone tissue engineering.

Table 1. Ion doped hydroxyapatite and the enhanced biological function studies.

\begin{tabular}{ccc}
\hline Doped Ions & Function & Reference \\
\hline \multirow{2}{*}{ Sr-HA } & Mechanical properties & {$[26-28]$} \\
& Biocompatibility & {$[27,28]$} \\
& Osteogenic activity & {$[29-34]$} \\
\hline \multirow{2}{*}{ Zn-HA } & Osteogenic activity & {$[39-41]$} \\
& Antibacterial & {$[43-45]$} \\
\hline Ag-HA & Antibacterial & {$[48-54]$} \\
\hline \multirow{2}{*}{ Si-HA } & Biomineralization & {$[57,58]$} \\
& Osteogenic activity & {$[59-61]$} \\
\hline \multirow{2}{*}{ F-HA } & Biomineralization & {$[62,65-67]$} \\
& Antibacterial & {$[28,71-74]$} \\
\multirow{2}{*}{ Mg-HA } & Osteogenic activity & {$[68-70,73,75]$} \\
& Osteogenic activity & {$[76]$} \\
Cu-HA & Antibacterial & {$[77,78]$} \\
\hline Mn-HA & Antibacterial & {$[79,80]$} \\
\hline Co-HA & Osteoblast differentiation & {$[81]$} \\
\hline & Osteogenic activity & {$[82]$} \\
\hline
\end{tabular}

\section{Hydroxyapatite/Biodegradable Polymer Composites Used for Bone Tissue Engineering}

In principle, biodegradable polymers with sufficient mechanical strength, optimized structure and appropriate degradation rate are desirable scaffold materials for bone tissue engineering $[84,85]$. The scaffold material should also be osteoconductive so that osteoblasts can adhere to the scaffold and migrate, differentiate, and eventually form new bone; thus various polymers have been blended with $\mathrm{HA}$ to combine the advantages of both polymer and HA. Biodegradable polymers, such as poly(lactic acid) (PLA) [86], poly(glycolic acid) (PGA), poly(lactide-co-glycolide) (PLGA) [87], and chitosan (CS) [88,89] have been widely used to develop hydroxyapatite/polymer biodegradable scaffolds for bone regeneration.

\subsection{Hydroxyapatite/Polylactic Acid (HA/PLA) Composites}

Polylactic acid (PLA) is a kind of linear aliphatic thermoplastic biodegradable polyester with good mechanical properties, thermoplastic and biocompatibility, and is easy to prepare [90]. It has become a promising polymer for various applications in the biomedical field. Since the 1980s, the research on HA/PLA composites has aroused much attention. In the recent ten years, the mechanical properties, biocompatibility and osteogenic properties of HA/PLA composites have been well investigated [91-93]. 
The content of HA will affect the mechanical properties of HA/PLA composites; furthermore, the HA/PLA composites have been prepared into various bone repair medical devices, such as the miniscrew and microplate. Y. Shikinami's group used PLA composites with $30 \mathrm{wt} \%$ HA content for the miniscrew and $40 \mathrm{wt} \%$ HA for the microplate, respectively. It was found that although the mechanical property of the composite device was slightly lower than that of natural cortical bone, its strength was much higher than that of pure PLA, and it had excellent fatigue resistance. It can maintain $70 \%$ of the initial strength even after alternating bending 60 times, without any damage, while the metal device fully broke off 8 times [94]. There were also many other types of HA/PLA composites, for example, to mimic the nano-fribrous structure of natural extracellular matrix, nano-fibrous HA/PLA porous scaffold was fabricated by thermally induced phase separation (TIPS) method; the compressive modulus of pure PLA scaffold was only $0.2 \mathrm{MPa}$, while that of HA/PLA composite scaffold at 20:80 (weight ratio) was as high as $0.63 \mathrm{MPa}$, which was about three times that of pure PLA [95].

HA/PLA showed good biocompatibility in cell adhesion and proliferation towards MC3T3-E1 osteoblast precursor cells, MG-63 osteosarcoma cell and L929 fibroblast cells, and the expression of bone specific marker (osteocalcin) was increased [96-98]. Cell survival and adhesion can be regulated by protein preadsorption on the substrates [99]. The protein adsorption of HA/PLA composite scaffolds was studied by incubating the scaffolds in FBS/PBS solution. The addition of HA increased the adsorption capacity of protein. Compared with the PLA scaffold, HA/PLA 50:50 and HA/PLA 70:30 composite scaffolds absorbed 2.4 and 3.2 times serum protein, respectively [100].

HA/PLA composites can improve osteogenic response in vitro and osteogenesis in vivo [101-103]. In pure PLA scaffolds, osteoblasts mainly adhered to the outer surface of the polymer. In contrast, osteoblasts were embedded into HA/PLA scaffolds and distributed evenly, and when cultured in vitro for 6 weeks, the expression of bone specific markers (coding bone sialoprotein and osteocalcin) was more abundant in HA/PLA [104]. The ALP of the HA/PLA composite fiber was significantly higher than that of the pure PLA fiber after 7 days culture [101]. Based on these in vitro results, HA/PLA nanocomposite fibers are believed to promote the adhesion and growth of osteoblasts and stimulate them to play the functional activities of bone related cells.

HA/PLA composite has been widely investigated. However, the biodegradable acid product of PLA may have a negative effect; while HA can effectively neutralize the acidic products, creating a microenvironment conducive to wound healing and bone formation, some in vivo results have demonstrated that HA/PLA scaffolds had good osteogenic capability showing their potential as bone graft substitutes in reconstructive surgery [105]. In order to fulfil improving the functions of HA/PLA scaffolds, other materials such as collagen or growth factors may be blended with HA/PLA; for example, PLA/HA/collagen scaffold loaded with recombinant human bone morphogenetic protein 2 (rh-BMP 2) was implanted into the defect site of rabbit radius. After 12 weeks, the scaffold was completely fused with the defect area, showing the replacement of new bone (trabecular) tissue [106], and demonstrating the bone regeneration of HA/PLA composite materials.

\subsection{Hydroxyapatite/Poly (Lactic Acid-co-Glycolic Acid) (HA/PLGA) Composites}

In view of the good biocompatibility and mechanical properties, PLGA has been widely used in drug delivery, and skin, nerve and bone tissue regeneration [107-110]. The compressive strength of PLGA is not enough for any load bearing application; HA can reinforce the mechanical properties of PLGA. Fisher et al. prepared HA/PLGA composites and found that composites with 30\% wt HA showed much better mechanical properties than that of PLGA; the strength of the composite was three times that of the polymer, and the compression modulus was also increased by six times. By injecting the injectable HA/PLGA scaffold material into the femoral head model, the compress modulus and strength of the trabecular increased from $3.5 \mathrm{MPa}$ to $5.9 \mathrm{MPa}$ and from 81 to $180 \mathrm{MPa}$, respectively [111]. 
HA/PLGA had better biocompatibility than pure PLGA. MTT assay was used to detect the metabolic activity of MC3T3-E1 cells at $1 \mathrm{~d}, 4 \mathrm{~d}$ and $7 \mathrm{~d}$. It was found that cell proliferation in the HA/PLGA group was significantly higher than that of the PLGA group on day 4 and 7 [112]. Compared with PLGA scaffold, HA/PLGA scaffold co-cultured with MSC had better cell adhesion, increasing cell proliferation ability and stronger ALP activity [113].

HA/PLGA has improved osteogenic compared with PLGA. MC3T3-E1 cells were inoculated on PLGA/HA/GO nanofibers; after 7 days of culture, the expression of Runx-2 in HA/PLGA nanofiber matrix was significantly higher than that in the PLGA nanofiber group. After 21 days of culture, the amount of ALP and calcium deposition in the HA/PLGA group was 1.5 and 2.3 times higher than that in the PLGA group, respectively [112]. Petrica and colleagues produced HA/PLGA composites and found that 30\% HA added into the polymer would maximize the material osteoconductivity [114]. In the animal experiment of mandibular defect, HA/PLGA scaffold showed a small amount of trabecular bone formed by osteoblasts at 6 weeks, and transformed into mature bone tissue at the end of 12 weeks, but it took 48 weeks for the PLGA control scaffold to form mature bone tissue to fill the defect [115]. The mechanism may be related to the addition of hydroxyapatite, which is more favorable to the deposition of calcium and phosphorus ions, and the fact that HA can reduce the degradation rate of PLGA and control the $\mathrm{pH}$ value during degradation.

\subsection{Hydroxyapatite/Chitosan (HA/CS) Composite}

Chitosan (CS) is a copolymer of D-glucosamine and N-acetyl-D-glucosamine [116]. Due to its biodegradable, non-toxic, antibacterial and biocompatible properties, CS can be used as a scaffold material or growth factor carrier in bone tissue engineering, and has attracted much attention $[117,118]$. Unfortunately, pure chitosan scaffolds have poor mechanical properties, and lack osteoconductivity. HA nanoparticles can be blended into the chitosan matrix to prepare chitosan-based composites with the potential of bionic natural bone [119,120].

The introduction of HA into chitosan can improve the mechanical properties of CS composite, and has been reported to be used in bone-filling paste and bone tissue engineering [121,122]. The aggregation of HA nanoparticles is a drawback of this kind of material, however, $\mathrm{Hu}$ et al. proposed a simple in situ hybridization method to prepare HA/CS nanocomposites, which can solve the aggregation problem. The initial mechanical properties of bending strength and modulus of the composite are $86 \mathrm{MPa}$ and $3.4 \mathrm{Gpa}$, which are much higher than those of bone cement, demonstrating their potential application for internal fixation of long bone fractures [123]. HA/CS scaffold also possesses quite good biocompatibility. Compared with pure chitosan scaffold, HA/CS composite enhanced cell adhesion, spreading and proliferation of human mesenchymal stem cells (hMSCs) [124,125].

$\mathrm{HA} / \mathrm{CS}$ biocomposites can induce osteoinduction and osseointegration, and promoted bone formation in different bone defects $[126,127]$. HA/CS and pure chitosan were implanted into the left femoral condyle of 43 adult New Zealand white rabbits to repair the femoral condyle defect (6 mm diameter, $10 \mathrm{~mm}$ length). The results showed that after 12 weeks of surgery, complete healing of the segmental bone defects was observed in rabbits implanted with the HA/CS scaffold, while the defects were still observed in the pure chitosan group [128]. HA/CS composite can also be used as a functional coating on other implants to produce biomaterials with excellent ossteoinduction properties. For example, Wang et al. coated HA/CS on a titanium surface (denoted as: cTi) and used them under diabetic conditions [129]. The histological analysis at the bone/implant interface showed that after 4 weeks, little regenerative bone was integrated into Ti or cTi. However, after 12 weeks, more bone contact was observed and a larger amount of new bone grew into the cTi implant than it did into the Ti implants (Figure 3) [129]. 


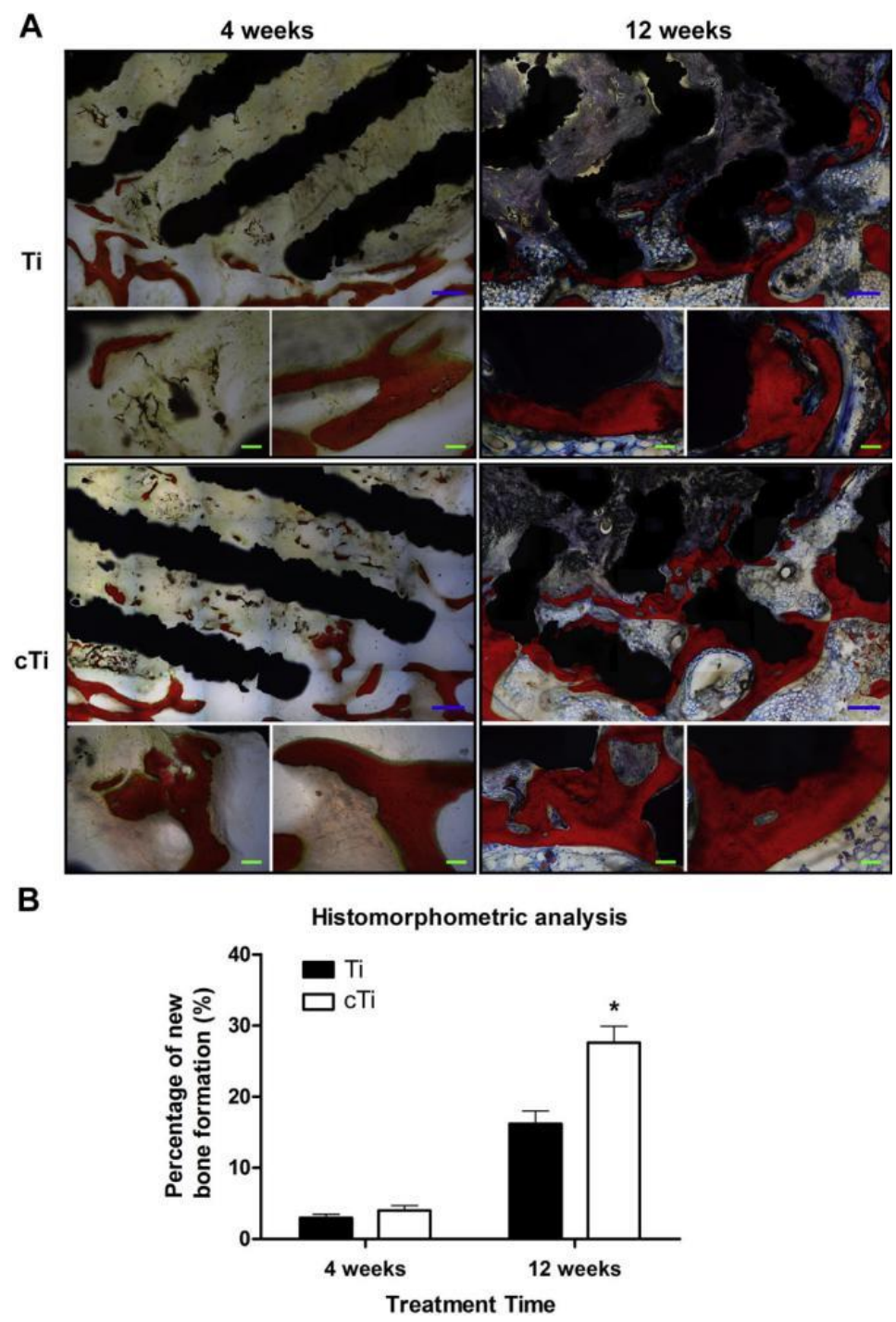

Figure 3. Histological examination of osteointegration at 4 and 12 weeks after implantation. (A) Van Gieson staining. The tissue stained in red color: the newly formed bone with visible cell nucleus. The tissue stained in dark blue color: fibrous tissue. (B) Histomorphometric measurement of new bone formation within the implants. $\left(^{*} p<0.05\right)$ [129].

\subsection{Hydroxyapatite/Other Degradable Polymers}

There are many other HA/degradable polymer composites, such as HA/collagen, $\mathrm{HA} /$ gelatin and HA/PCL; these are widely investigated in bone tissue engineering. All these composites have proper mechanical and exciting bioproperties. HA/collagen was improved in term of adhesion, proliferation and differentiation of seeded MSCs [130]. $\mathrm{HA} /$ gelatin composite can increase the elastic modulus and decrease the toughness of the scaffold with increasing HA content; the compressive modulus was about $180 \mathrm{MPa}$ which was very similar to that of natural sponge bone [131]. As for hydroxyapatite polycaprolactone (HA/PCL) composite, when the volume ratio of HA increased from $0 \%$ to $30 \%$, the elastic modulus of HA/PCL scaffold increased from 299.3 to $498.3 \mathrm{MPa}$, and the compressive modulus was 2.4 times that of PCL [132]. Furthermore, the porous HA/PCL scaffolds could improve the proliferation and cell viability of primary fetal bovine osteoblasts more effectively than PCL scaffolds [133].

These composites can make full use of the advantages of different biodegradable materials and have broad prospects in bone tissue engineering. However, during the preparation of composites, HA nanoparticles may agglomerate easily, which induce early 
failure at the interface, limiting the application of the composites [134]. Therefore, it is of great significance to study the dispersion of nanoparticles in the polymer matrix, and thus many works have been carried out to tune the surface properties of HA and improve its phase compatibility with the polymer matrix.

\section{Surface Modified HA and Its Polymer Composites}

\subsection{Surface Modification of HA Nanoparticles}

The surface of HA can be modified to have unique properties by selecting different functional composites. The most important methods of surface modification can be divided into "grafting to" or "grafting from" approaches [135,136].

One of the most important reactions for surface modification of HA is the condensation reaction, such as esterification and amidation. In 1996, Liu et al. developed a method to modify the surface of hydroxyapatite with polyelectrolyte polyacrylic acid (PAA) in an aqueous solution, and then the modified HA was used as fillers to blend with polyactive $\mathrm{TM}_{70 / 30}$. The elongation at break, tensile strength and elastic modulus of the composite can be significantly improved by this method [137]. In addition, the research group also used poly(ethylene-co-maleic acid) (PEMA) to tune the surface properties of HA. The mechanical properties of the composites can be significantly improved in both dry and wet states. Fracture analysis showed that the surface modified hydroxyapatite particles maintained good contact at the fracture site [138].

PLLA can be grafted onto the surface of HA nanoparticles via the polycondensation method and form PLLA grafted HA (p-HA) [139]. The surface grafted PLLA may increase the compatibility between HA and the polymer matrix, and thus the mechanical properties of p-HA/PLLA were improved. The tensile strength of $\mathrm{p}-\mathrm{HA} / \mathrm{PLLA}$ is $68.7 \mathrm{MPa}$, while that of HA/PLLA is only $43 \mathrm{MPa}$ [139]. Hong and colleagues prepared p-HA nanoparticles via the Ring-opening polymerization of L-lactide [140]; p-HA can be dispersed more homogeneously in chloroform. Compared with HA/PLLA composites, p-HA/PLLA composites have better mechanical properties. When the content of $\mathrm{p}-\mathrm{HA}$ was $4 \mathrm{wt} \%$, the tensile strength was about $75 \mathrm{MPa}$, about $13 \%$ higher than that of PLLA $[140,141]$.

Organic coupling agent can also be used to tune the surface of hydroxyapatite nanoparticles; the functional groups of the coupling agent can react with other materials, and thus it is an effective method to prepare surface modified HA via the coupling agent as a bridge molecule. For example, 3-aminopropyltriethoxysilane (APES) can react with carboxyl containing polymers or other organic molecules by amidation, and then graft onto inorganic particles by condensation of the silane alcohol groups [142]. Chen's group prepared a novel HA hybrid material by surface modification with electroactive aniline tetramers [143]. The method is simple, and can be used widely in the grafting of other functional groups or polymers on the surface of HA. Rakmae et al. reported that APES or 3-methacryloyloxypropyltrimethoxysilane could be used to modify the surface of HA particles to increase the compatibility between inorganic fillers and the polymer matrix, and significantly improve the mechanical and thermal properties of the composites [144]. In addition, 2-carboxyethylphosphonic acid (CEPA) is another coupling agent and can be used to modify the surface of HA particles. When CEPA modified HA(C-HA) was blended with PLA, the results showed that C-HA dispersed homogeneously in the PLLA matrix, which can improve the interfacial interaction between the PLA matrix and the nanoparticles. The tensile strength and modulus of C-HA/PLA scaffold containing 20\% C-HA were 1.4 and 2.79 times higher, respectively, than those of HA/PLA [145].

HA can also be chemically modified by drugs, proteins and growth factors through various technologies, which may greatly improve the applications of HA. Huang et al. proposed a simple method to graft bone morphogenetic protein-2 (BMP-2) on the surface of HA nanoparticles, which may preserve the bioactivity and slow release of BMP-2 [146]. When the BMP-2 modified HA (HA-BMP) was blended with gelatin methacrylamide and four-armed PEG methacrylamide, the BMP-2 may also increase the phase interaction between HA and polymer chains via hydrogen bounding; more importantly, when the 
composite was implanted in a rat skull defect model, the new bone volume and osteogenesis rate were as high as $50.54 \pm 13.51 \mathrm{~mm}$ and $64.38 \pm 17.22 \%$, respectively, showing great potential in bone regeneration therapy [146].

\subsection{Application of Surface Modified HA in Bone Tissue Engineering}

The surface modification of HA can adjust its surface properties, and may improve the phase compatibility between HA and polymers, and thus the modified HA/polymer composites may show much better mechanical properties than that of pure HA/polymer, which may promote their application in bone tissue engineering. Zhang et al. prepared 3-D porous scaffold with PLA grafted HA/PLGA (p-HA/PLGA) composite and investigated the mineralization and osteogenesis properties via in vivo rabbit radius repair experiments. The results showed that $\mathrm{p}-\mathrm{HA} / \mathrm{PLGA}$ scaffold was more stable than PLGA, and the biodegradability and degree of mineralization were similar to those of HA/PLGA. The in vivo results showed that the p-HA/PLGA scaffolds loaded with BMP-2 have much better osteogenesis properties than PLGA; after 4 and 8 weeks post-surgery, the bone bridges were more perfect and smooth than those in the PLGA group (Figure 4) [147]. Cui et al. also prepared a p-HA/PLGA scaffold with various p-HA content, and used it for bone repair experiments. Their in vivo results showed that the scaffolds could promote bone healing very well [148]. Song et al. used p-HA as nanofiller to prepare a p-HA/PLGA nanofiber membrane via the electrospinning method, and investigated their mechanical and invitro bioproperties. The results demonstrated that the surface modification of HA improved the dispersion of HA particles in the PLGA matrix; furthermore, the bioactivity test and biocompatibility test suggested that the bioresorbable p-HA/ / PLGA composite fiber membranes could be utilized for guided bone regeneration [149]. Wei et al. prepared poly ( $\gamma$-benzyl-L-glutamate) modified hydroxyapatite/(poly (L-lactic acid)) (PBLG-g-HA/PLLA) composite scaffolds, and their osteogenic properties were investigated by analyzing new bone formation in 3 $\mathrm{mm}$ bilateral femur defects in 18 Wistar female rats in vivo. The results showed that the PBLG-g-HA/PLLA scaffold had good osteogenic properties and may have broad applications in bone tissue engineering [150]. Up to now, the research and application of polymer modified HA and their composites are still very limited, however, due to their merits in improving the mechanical and biological properties, this kind of composite should arouse increasing attention in engineering bone tissue scaffolds.
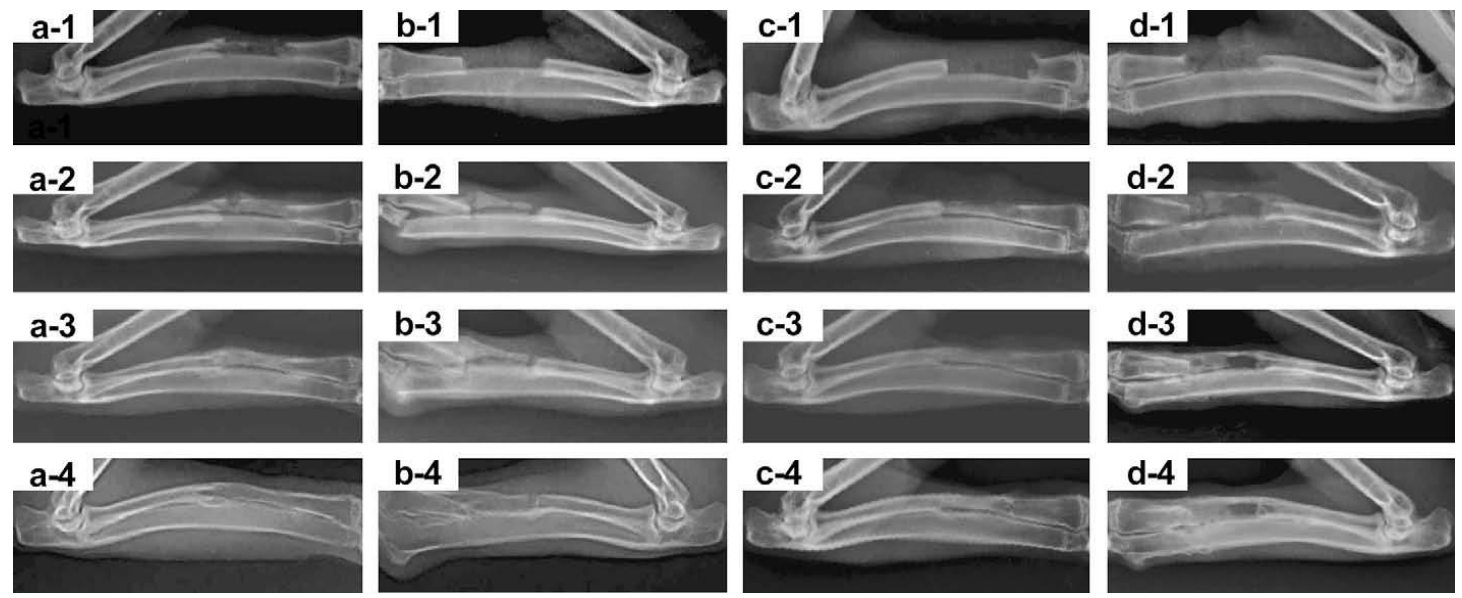

Figure 4. The rabbit radius defects implanted with the porous scaffolds of BMP-2/p-HA/PLGA (a-1-4), p-HA/PLGA (b-1-4), HA/PLGA (c-1-4), and PLGA (d-1-4) at 0, 2, 4 and 8 weeks post-surgery [147].

\section{Prospective}

Bone tissue engineering is a promising method to realize the construction of new bone tissue and to rebuild bone functions. HA, due to its similarity to natural bone's 
composition, showed great potential applications. In this review, HA-based materials were briefly introduced; the content covered inorganic materials and polymer composites, which may be helpful for readers to get a comprehensive understanding about HA. We think it may fall in the interest points of material science or clinic investigators who are interested in bone tissue engineering or bone regeneration.

Although many works have been done, in particular, substantial progress has been made in developing materials with sufficient mechanical strength, there are still great challenges to prepare ideal tissue engineering scaffolds with HA as the nano-building block. With the understanding of natural bone structure and the microenvironment for bone regeneration, an increasing number of biomimetic structure scaffolds based on HA will be investigated. Furthermore, new biomimetic or bioinspired methods will be proposed to prepare various HA based scaffolds. The use of HA particles as a key building block serves as a basis for multifunctional HA particles which can satisfy the tissue microenvironment or conquer clinical challenges and will arouse increasing attention.

Author Contributions: Conceptualization, J.W. and H.S.; writing-original draft preparation, H.S., Z.Z. and W.L.; writing-review and editing, J.W. and Y.F.; supervision, Z.L.; project administration, Z.L. and J.W.; funding acquisition, Z.L. and J.W. All authors have read and agreed to the published version of the manuscript.

Funding: This research was funded by the National Natural Science Foundation of China (No. 51663017\&81960205) and Jiangxi Key Research and Development Program (20202BBG73012).

Conflicts of Interest: The authors declare no conflict of interest.

\section{References}

1. Balogh, Z.J.; Reumann, M.K.; Gruen, R.L.; Mayer-Kuckuk, P.; Schuetz, M.A.; Harris, I.A.; Gabbe, B.J.; Bhandari, M. Advances and future directions for management of trauma patients with musculoskeletal injuries. Lancet 2012, 380, 1109-1119. [CrossRef]

2. Langer, R.; Vacanti, J.P. Tissue Engineering. Science 1993, 260, 920-926. [CrossRef] [PubMed]

3. Pegg, D.E. Principles of Tissue Engineering. Cryobiology 1999, 39, 378-379. [CrossRef]

4. Burg, K.J.; Porter, S.; Kellam, J.F. Biomaterial developments for bone tissue engineering. Biomaterials 2000, 21, $2347-2359$. [CrossRef]

5. Shah, N.J.; Mao, A.S.; Shih, T.Y.; Kerr, M.D.; Sharda, A.; Raimondo, T.M.; Weaver, J.C.; Vrbanac, V.D.; Deruaz, M.; Tager, A.M.; et al. An injectable bone marrow-like scaffold enhances $\mathrm{T}$ cell immunity after hematopoietic stem cell transplantation. Nat. Biotechnol. 2019, 37, 293-302. [CrossRef] [PubMed]

6. Zhao, R.; Xie, P.; Zhang, K.; Tang, Z.; Chen, X.; Zhu, X.; Fan, Y.; Yang, X.; Zhang, X. Selective effectof hydroxyapatite nanoparticles on osteoporotic and healthy bone formation correlates with intracellular calcium homeostasis regulation. Acta Biomater. 2017, 59, 338-350. [CrossRef] [PubMed]

7. Murugan, R.; Ramakrishna, S. Bioresorbable composite bone paste using polysaccharide based nano hydroxyapatite. Biomaterials 2004, 25, 3829-3835. [CrossRef]

8. LeGeros, R.Z. Calcium phosphate-based osteoinductive materials. Chem. Rev. 2008, 108, 4742-4753. [CrossRef] [PubMed]

9. Oliveira, H.L.; Da Rosa, W.L.O.; Cuevas-Suárez, C.E.; Carre, O.N.L.V.; Da Silva, A.F.; Guim, T.N.; Dellagostin, O.A.; Piva, E. Histological Evaluation of Bone Repair with Hydroxyapatite: A Systematic Review. Calcified. Tissue Int. 2017, 101, 314-325. [CrossRef]

10. Szczes, A.; Holysz, L.; Chibowski, E. Synthesis of hydroxyapatite for biomedical applications. Adv. Colloid Interface Sci. 2017, 249, 321-330. [CrossRef]

11. Koons, G.L.; Diba, M.; Mikos, A.G. Materials design for bone-tissue engineering. Nat. Rev. Mater. 2020, 5, 584-603. [CrossRef]

12. Arcos, D.; Vallet-Regi, M. Substituted hydroxyapatite coatings of bone implants. J. Mater. Chem. B 2020, 8, 1781-1800. [CrossRef] [PubMed]

13. Molino, G.; Palmieri, M.C.; Montalbano, G.; Fiorilli, S.; Vitale-Brovarone, C. Biomimetic and mesoporous nano-hydroxyapatite for bone tissue application: A short review. Biomed. Mater. 2020, 15, 22001. [CrossRef] [PubMed]

14. Choi, G.; Choi, A.H.; Evans, L.A.; Akyol, S.; Ben-Nissan, B. A review: Recent advances in sol-gel-derived hydroxyapatite nanocoatings for clinical applications. J. Am. Ceram. Soc. 2020, 103, 5442-5453. [CrossRef]

15. Awasthi, S.; Pandey, S.K.; Arunan, E.; Srivastava, C. A review on hydroxyapatite coatings for the biomedical applications: Experimental and theoretical perspectives. J. Mat. Chem. B 2021. [CrossRef]

16. Safarzadeh, M.; Ramesh, S.; Tan, C.Y.; Chandran, H.; Noor, A.F.M.; Krishnasamy, S.; Alengaram, U.J.; Ramesh, S. Effect of multi-ions doping on the properties of carbonated hydroxyapatite bioceramic. Ceram. Int. 2019, 45, 3473-3477. [CrossRef]

17. Driessens, F.C.; Boltong, M.G.; de Maeyer, E.A.; Wenz, R.; Nies, B.; Planell, J.A. The Ca/P range of nanoapatitic calcium phosphate cements. Biomaterials 2002, 23, 4011-4017. [CrossRef] 
18. Webster, T.J.; Ergun, C.; Doremus, R.H.; Bizios, R. Hydroxyapatite with substituted magnesium, zinc, cadmium, and yttrium. II. Mechanisms of osteoblast adhesion. J. Biomed. Mater. Res. 2002, 59, 312-317. [CrossRef]

19. Porter, A.E.; Patel, N.; Skepper, J.N.; Best, S.M.; Bonfield, W. Comparison of in vivo dissolution processes in hydroxyapatite and silicon-substituted hydroxyapatite bioceramics. Biomaterials 2003, 24, 4609-4620.

20. Luo, X.; Barbieri, D.; Davison, N.; Yan, Y.; de Bruijn, J.D.; Yuan, H. Zinc in calcium phosphate mediates bone induction: In vitro and in vivo model. Acta Biomater. 2014, 10, 477-485. [CrossRef]

21. Rachner, T.D.; Khosla, S.; Hofbauer, L.C. Osteoporosis: Now and the future. Lancet 2011, 377, 1276-1287. [CrossRef]

22. Canalis, E.; Hott, M.; Deloffre, P.; Tsouderos, Y.; Marie, P.J. The divalent strontium salt S12911 enhances bone cell replication and bone formation in vitro. Bone 1996, 18, 517-523. [CrossRef]

23. Ammann, P.; Shen, V.; Robin, B.; Mauras, Y.; Bonjour, J.P.; Rizzoli, R. Strontium ranelate improves bone resistance by increasing bone mass and improving architecture in intact female rats. J. Bone. Miner. Res. 2004, 19, 2012-2020. [CrossRef] [PubMed]

24. Maciel, P.P.; Pessa, J.A.M.; Medeiros, E.L.G.D.; Batista, A.U.D.; Bonan, P.R.F. Use of strontium doping glass-ceramic material for bone regeneration in critical defect: In vitro and in vivo analyses. Ceram. Int. 2020, 46, 24940-24954. [CrossRef]

25. Koutsoukos, P.G.; Nancollas, G.H. Influence of strontium ion on the crystallization of hydroxyapatite from aqueous solution. J. Phys. Chem. 1981, 85, 62-71. [CrossRef]

26. Guo, D.; Xu, K.; Zhao, X.; Han, Y. Development of a strontium-containing hydroxyapatite bone cement. Biomaterials 2005, 26, 4073-4083. [CrossRef]

27. Frasnelli, M.; Cristofaro, F.; Sglavo, V.M.; Dirè, S.; Visai, L. Synthesis and characterization of strontium-substituted hydroxyapatite nanoparticles for bone regeneration. Mater. Sci. Eng. C Mater. Biol. Appl. 2017, 71, 653-662. [CrossRef]

28. Wang, Q.; Li, P.; Tang, P.; Ge, X.; Ren, F.; Zhao, C.; Fang, J.; Wang, K.; Fang, L.; Li, Y.; et al. Experimental and simulation studies of strontium/fluoride-codoped hydroxyapatite nanoparticles with osteogenic and antibacterial activities. Colloids Surf. B Biointerfaces 2019, 182, 110359. [CrossRef]

29. Bianchi, M.; Degli Esposti, L.; Ballardini, A.; Liscio, F.; Berni, M.; Gambardella, A.; Leeuwenburgh, S.C.G.; Sprio, S.; Tampieri, A.; Iafisco, M. Strontium doped calcium phosphate coatings on poly(etheretherketone) (PEEK) by pulsed electron deposition. Surf. Coat. Tech. 2017, 319, 191-199. [CrossRef]

30. Yang, F.; Yang, D.; Tu, J.; Zheng, Q.; Cai, L.; Wang, L. Strontium enhances osteogenic differentiation of mesenchymal stem cells and in vivo bone formation by activating Wnt/catenin signaling. Stem Cells 2011, 29, 981-991. [CrossRef]

31. Capuccini, C.; Torricelli, P.; Sima, F.; Boanini, E.; Ristoscu, C.; Bracci, B.; Socol, G.; Fini, M.; Mihailescu, I.N.; Bigi, A. Strontiumsubstituted hydroxyapatite coatings synthesized by pulsed-laser deposition: In vitro osteoblast and osteoclast response. Acta Biomater. 2008, 4, 1885-1893. [CrossRef] [PubMed]

32. Zhou, J.; Li, B.; Lu, S.; Zhang, L.; Han, Y. Regulation of osteoblast proliferation and differentiation by interrod spacing of Sr-HA nanorods on microporous titania coatings. ACS Appl. Mater. Interfaces 2013, 5, 5358-5365. [CrossRef] [PubMed]

33. Gao, L.; Huang, Z.; Yan, S.; Zhang, K.; Xu, S.; Li, G.; Cui, L.; Yin, J. Sr-HA-graft-Poly(gamma-benzyl-l-glutamate) Nanocomposite Microcarriers: Controllable $\mathrm{Sr}^{2+}$ Release for Accelerating Osteogenenisis and Bony Nonunion Repair. Biomacromolecules 2017, 18, 3742-3752. [CrossRef] [PubMed]

34. Ni, G.X.; Lu, W.W.; Chiu, K.Y.; Li, Z.Y.; Fong, D.Y.; Luk, K.D. Strontium-containing hydroxyapatite (Sr-HA) bioactive cement for primary hip replacement: An in vivo study. J. Biomed. Mater. Res. Part B 2006, 77, 409-415. [CrossRef] [PubMed]

35. Busse, B.; Jobke, B.; Hahn, M.; Priemel, M.; Niecke, M.; Seitz, S.; Zustin, J.; Semler, J.; Amling, M. Effects of strontium ranelate administration on bisphosphonate-altered hydroxyapatite: Matrix incorporation of strontium is accompanied by changes in mineralization and microstructure. Acta Biomater. 2010, 6, 4513-4521. [CrossRef] [PubMed]

36. Kabir, H.; Munir, K.; Wen, C.; Li, Y. Recent research and progress of biodegradable zinc alloys and composites for biomedical applications: Biomechanical and biocorrosion perspectives. Bioact. Mater. 2021, 6, 836-879. [CrossRef]

37. Coleman, J.E. Zinc proteins: Enzymes, storage proteins, transcription factors, and replication proteins. Annu. Rev. Biochem. 1992, 61, 897-946. [CrossRef]

38. Hoppe, A.; Guldal, N.S.; Boccaccini, A.R. A review of the biological response to ionic dissolution products from bioactive glasses and glass-ceramics. Biomaterials 2011, 32, 2757-2774. [CrossRef]

39. Chopra, V.; Thomas, J.; Sharma, A.; Panwar, V.; Kaushik, S.; Sharma, S.; Porwal, K.; Kulkarni, C.; Rajput, S.; Singh, H.; et al. Synthesis and Evaluation of a Zinc Eluting rGO/Hydroxyapatite Nanocomposite Optimized for Bone Augmentation. ACS Biomater. Sci. Eng. 2020, 6, 6710-6725. [CrossRef]

40. Toledano, M.; Osorio, R.; Vallecillo-Rivas, M.; Osorio, E.; Lynch, C.D.; Aguilera, F.S.; Toledano, R.; Sauro, S. Zn-doping of silicate and hydroxyapatite-based cements: Dentin mechanobiology and bioactivity. J. Mech. Behav. Biomed. Mater. 2020, $114,104232$. [CrossRef]

41. Martinez-Zelaya, V.R.; Zarranz, L.; Herrera, E.Z.; Alves, A.T.; Uzeda, M.J.; Mavropoulos, E.; Rossi, A.L.; Mello, A.; Granjeiro, J.M.; Calasans-Maia, M.D.; et al. In vitro and in vivo evaluations of nanocrystalline Zn-doped carbonated hydroxyapatite/alginate microspheres: Zinc and calcium bioavailability and bone regeneration. Int. J. Nanomed. 2019, 14, 3471-3490. [CrossRef] [PubMed]

42. Jallot, E.; Nedelec, J.M.; Grimault, A.S.; Chassot, E.; Grandjean-Laquerriere, A.; Laquerriere, P.; Laurent-Maquin, D. STEM and EDXS characterisation of physico-chemical reactions at the periphery of sol-gel derived Zn-substituted hydroxyapatites during interactions with biological fluids. Colloids Surf. B Biointerfaces 2005, 42, 205-210. [CrossRef] [PubMed] 
43. Rachele, S.; Devis, B.; Candidato, R.T.; Luca, L.; Giovanni, B.; Lech, P.; Gabriele, C.; Lina, A.; Luigi, D.N.; Valeria, C. Bioactive Zn-doped hydroxyapatite coatings and their antibacterial efficacy against Escherichia coli and Staphylococcus aureus. Surf. Coat. Tech. 2018, 352, 84-91.

44. de Lima, C.O.; de Oliveira, A.; Chantelle, L.; Silva, F.E.; Jaber, M.; Fonseca, M.G. Zn-doped mesoporous hydroxyapatites and their antimicrobial properties. Colloids Surf. B Biointerfaces 2020, 111471. [CrossRef] [PubMed]

45. Predoi, D.; Iconaru, S.; Predoi, M.; Buton, N.; Motelica-Heino, M. Zinc Doped Hydroxyapatite Thin Films Prepared by Sol-Gel Spin Coating Procedure. Coatings 2019, 9, 156. [CrossRef]

46. Kim, J.S.; Kuk, E.; Yu, K.N.; Kim, J.H.; Park, S.J.; Lee, H.J.; Kim, S.H.; Park, Y.K.; Park, Y.H.; Hwang, C.Y.; et al. Antimicrobial effects of silver nanoparticles. Nanomedicine 2007, 3, 95-101. [CrossRef]

47. Rai, M.; Yadav, A.; Gade, A. Silver nanoparticles as a new generation of antimicrobials. Biotechnol. Adv. 2009, 27, 76-83. [CrossRef]

48. Mirzaee, M.; Vaezi, M.; Palizdar, Y. Synthesis and characterization of silver doped hydroxyapatite nanocomposite coatings and evaluation of their antibacterial and corrosion resistance properties in simulated body fluid. Mater. Sci. Eng. C-Mater. Biol. Appl. 2016, 69, 675-684. [CrossRef]

49. Roy, M.; Fielding, G.A.; Beyenal, H.; Bandyopadhyay, A.; Bose, S. Mechanical, in vitro antimicrobial, and biological properties of plasma-sprayed silver-doped hydroxyapatite coating. ACS Appl. Mater. Interfaces 2012, 4, 1341-1349. [CrossRef]

50. Ciobanu, C.S.; Massuyeau, F.; Constantin, L.V.; Predoi, D. Structural and physical properties of antibacterial Ag-doped nanohydroxyapatite synthesized at 100 degrees. Nanoscale Res. Lett. 2011, 6, 613. [CrossRef]

51. Bai, X.; Sandukas, S.; Appleford, M.; Ong, J.L.; Rabiei, A. Antibacterial effect and cytotoxicity of Ag-doped functionally graded hydroxyapatite coatings. J. Biomed. Mater. Res. Part B 2012, 100, 553-561. [CrossRef] [PubMed]

52. Jelinek, M.; Kocourek, T.; Jurek, K.; Remsa, J.; Miksovsky, J.; Weiserova, M.; Strnad, J.; Luxbacher, T. Antibacterial properties of Ag-doped hydroxyapatite layers prepared by PLD method. Appl. Phys. A 2010, 101, 615-620. [CrossRef]

53. Qiuhua, Y.; Anping, X.; Ziqiang, Z.; Zehui, C.; Lei, W.; Xin, S.; Songxin, L.; Zhiyang, Y.; Libo, D. Bioactive silver doped hydroxyapatite composite coatings on metal substrates: Synthesis and characterization. Mater. Chem. Phys. 2018, 218, 130-139.

54. Chen, W.; Liu, Y.; Courtney, H.S.; Bettenga, M.; Agrawal, C.M.; Bumgardner, J.D.; Ong, J.L. In vitro anti-bacterial and biological properties of magnetron co-sputtered silver-containing hydroxyapatite coating. Biomaterials 2006, 27, 5512-5517. [CrossRef]

55. Carlisle, E.M. Silicon: A possible factor in bone calcification. Science 1970, 167, 279-280. [CrossRef]

56. Gotz, W.; Tobiasch, E.; Witzleben, S.; Schulze, M. Effects of Silicon Compounds on Biomineralization, Osteogenesis, and Hard Tissue Formation. Pharmaceutics 2019, 11, 117. [CrossRef]

57. Fu, X.; Liu, P.; Zhao, D.; Yuan, B.; Xiao, Z.; Zhou, Y.; Yang, X.; Zhu, X.; Tu, C.; Zhang, X. Effects of Nanotopography Regulation and Silicon Doping on Angiogenic and Osteogenic Activities of Hydroxyapatite Coating on Titanium Implant. Int. J. Nanomed. 2020, 15, 4171-4189. [CrossRef]

58. Thian, E.S.; Huang, J.; Best, S.M.; Barber, Z.H.; Bonfield, W. Magnetron co-sputtered silicon-containing hydroxyapatite thin films-an in vitro study. Biomaterials 2005, 26, 2947-2956. [CrossRef]

59. Thian, E.S.; Huang, J.; Best, S.M.; Barber, Z.H.; Bonfield, W. Silicon-substituted hydroxyapatite: The next generation of bioactive coatings. Mater. Sci. Eng. C-Mater. Biol. Appl. 2007, 27, 251-256. [CrossRef]

60. Porter, A.E.; Patel, N.; Skepper, J.N.; Best, S.M.; Bonfield, W. Effect of sintered silicate-substituted hydroxyapatite on remodelling processes at the bone-implant interface. Biomaterials 2004, 25, 3303-3314. [CrossRef]

61. Patel, N.; Best, S.M.; Bonfield, W.; Gibson, I.R.; Hing, K.A.; Damien, E.; Revell, P.A. A comparative study on the in vivo behavior of hydroxyapatite and silicon substituted hydroxyapatite granules. J. Mater. Sci. Mater. Med. 2002, 13, 1199-1206. [CrossRef] [PubMed]

62. Stanic, V.; Dimitrijevic, S.; Antonovic, D.G.; Jokic, B.M.; Zec, S.P.; Tanaskovic, S.T.; Raicevic, S. Synthesis of fluorine substituted hydroxyapatite nanopowders and application of the central composite design for determination of its antimicrobial effects. Appl. Surf. Sci. 2014, 290, 346-352. [CrossRef]

63. Pak, C.Y.; Zerwekh, J.E.; Antich, P. Anabolic effects of fluoride on bone. Trends Endocrinol. Metab. 1995, 6, 229-234. [CrossRef]

64. Farley, J.R.; Tarbaux, N.; Hall, S.; Baylink, D.J. Evidence that fluoride-stimulated 3[H]-thymidine incorporation in embryonic chick calvarial cell cultures is dependent on the presence of a bone cell mitogen, sensitive to changes in the phosphate concentration, and modulated by systemic skeletal effectors. Metabolism 1988, 37, 988-995. [CrossRef]

65. Hashimoto, Y.; Ueda, M.; Kohiga, Y.; Imura, K.; Hontsu, S. Application of fluoridated hydroxyapatite thin film coatings using KrF pulsed laser deposition. Dent. Mater. J. 2018, 37, 408-413. [CrossRef] [PubMed]

66. Bakhsheshi-Rad, H.R.; Hamzah, E.; Daroonparvar, M.; Ebrahimi-Kahrizsangi, R.; Medraj, M. In-vitro corrosion inhibition mechanism of fluorine-doped hydroxyapatite and brushite coated $\mathrm{Mg}-\mathrm{Ca}$ alloys for biomedical applications. Ceram. Int. 2014, 40, 7971-7982. [CrossRef]

67. Pajor, K.; Pajchel, L.; Kolmas, J. Hydroxyapatite and Fluorapatite in Conservative Dentistry and Oral Implantology-A Review. Materials 2019, 12, 2683. [CrossRef]

68. Li, J.; Han, P.; Ji, W.; Song, Y.; Zhang, S.; Chen, Y.; Zhao, C.; Zhang, F.; Zhang, X.; Jiang, Y. The in vitro indirect cytotoxicity test and in vivo interface bioactivity evaluation of biodegradable FHA coated Mg-Zn alloys. Acta Biomater. 2011, 176, 1785-1788. [CrossRef]

69. Rao, Q.; Guo, X.; Fan, X.; Dai, B.; Wu, J.; Gong, M.; Wu, C. Fluoridation of synthetic apatite: Effect on the formation of calcium-deficient hydroxyapatite and the properties of porous scaffold. Ceram. Int. 2016, 42, 3442-3451. [CrossRef] 
70. Li, Z.; Huang, B.; Mai, S.; Wu, X.; Zhang, H.; Qiao, W.; Luo, X.; Chen, Z. Effects of fluoridation of porcine hydroxyapatite on osteoblastic activity of human MG63 cells. Sci. Technol. Adv. Mater. 2015, 16, 35006. [CrossRef]

71. Faidt, T.; Zeitz, C.; Grandthyll, S.; Hans, M.; Müller, F. Time Dependence of Fluoride Uptake in Hydroxyapatite. ACS Biomater. Sci. Eng. 2017, 3, 1822-1826. [CrossRef] [PubMed]

72. Yin, X.; Bai, Y.; Zhou, S.; Ma, W.; Bai, X.; Chen, W. Solubility, Mechanical and Biological Properties of Fluoridated Hydroxyapatite/Calcium Silicate Gradient Coatings for Orthopedic and Dental Applications. J. Therm. Spray Techn. 2020, 29, 471-488. [CrossRef]

73. Wang, L.; He, S.; Wu, X.; Liang, S.; Mu, Z.; Wei, J.; Deng, F.; Deng, Y.; Wei, S. Polyetheretherketone/nano-fluorohydroxyapatite composite with antimicrobial activity and osseointegration properties. Biomaterials 2014, 35, 6758-6775. [CrossRef]

74. Ge, X.; Leng, Y.; Bao, C.; Xu, S.L.; Wang, R.; Ren, F. Antibacterial coatings of fluoridated hydroxyapatite for percutaneous implants. J. Biomed. Mater. Res. Part A 2010, 95, 588-599. [CrossRef] [PubMed]

75. Kim, H.W.; Lee, E.J.; Kim, H.E.; Salih, V.; Knowles, J.C. Effect of fluoridation of hydroxyapatite in hydroxyapatite-polycaprolactone composites on osteoblast activity. Biomaterials 2005, 26, 4395-4404. [CrossRef]

76. Sartori, M.; Giavaresi, G.; Tschon, M.; Martini, L.; Dolcini, L.; Fiorini, M.; Pressato, D.; Fini, M. Long-term in vivo experimental investigations on magnesium doped hydroxyapatite bone substitutes. J. Mater. Sci. Mater. Med. 2014, 25, 1495-1504. [CrossRef]

77. Andres, N.C.; D’Elia, N.L.; Ruso, J.M.; Campelo, A.E.; Massheimer, V.L.; Messina, V.P. Manipulation of $\mathrm{Mg}^{2+}-\mathrm{Ca}^{2+}$ Switch on the Development of Bone Mimetic Hydroxyapatite. ACS Appl. Mater. Interfaces 2017, 9, 15698-15710. [CrossRef]

78. Andres, N.C.; Sieben, J.M.; Baldin, M.; Rodriguez, C.H.; Farniglietti, A.; Messina, V.P. Electroactive Mg ${ }^{2+}-\mathrm{Hydroxyapatite}$ Nanostructured Networks against Drug-Resistant Bone Infection Strains. ACS Appl. Mater. Interfaces 2018, 10, 19534-19544. [CrossRef]

79. Yu, W.; Sun, T.; Ding, Z.; Qi, C.; Zhao, H.; Chen, F.; Shi, Z.; Zhu, Y.; Chen, D.; He, Y. Copper-doped mesoporous hydroxyapatite microspheres synthesized by a microwave-hydrothermal method using creatine phosphate as an organic phosphorus source: Application in drug delivery and enhanced bone regeneration. J. Mater. Chem. B 2017, 5, 1039-1052. [CrossRef]

80. Hidalgo-Robatto, B.M.; López-álvarez, M.; Azevedo, A.S.; Dorado, J.; Serra, J.; Azevedo, N.F.; González, P. Pulsed laser deposition of copper and zinc doped hydroxyapatite coatings for biomedical applications. Surf. Coat. Technol. 2017, 33, 168-177. [CrossRef]

81. Sedghi, R.; Shaabani, A.; Sayyari, N. Electrospun triazole-based chitosan nanofibers as a novel scaffolds for bone tissue repair and regeneration. Carbohydr. Polym. 2020, 230, 115707. [CrossRef] [PubMed]

82. Kulanthaivel, S.; Roy, B.; Agarwal, T.; Giri, S.; Pramanik, K.; Pal, K.; Ray, S.S.; Maiti, T.K.; Banerjee, I. Cobalt doped proangiogenic hydroxyapatite for bone tissue engineering application. Mater. Sci. Eng. 2016, 58, 648-658. [CrossRef] [PubMed]

83. Graziani, G.; Bianchi, M.; Sassoni, E.; Russo, A.; Marcacci, M. Ion-substituted calcium phosphate coatings deposited by plasmaassisted techniques: A review. Mater. Sci. Eng. C-Mater. Biol. Appl. 2017, 74, 219-229. [CrossRef] [PubMed]

84. Nair, L.S.; Laurencin, C.T. Biodegradable polymers as biomaterials. Prog. Polym. Sci. 2007, 32, 762-798. [CrossRef]

85. Shuai, C.; Yang, W.; Feng, P.; Peng, S.; Pan, H. Accelerated degradation of HAP/PLLA bone scaffold by PGA blending facilitates bioactivity and osteoconductivity. Bioact. Mater. 2021, 6, 490-502. [CrossRef] [PubMed]

86. Madhavan, N.K.; Nair, N.R.; John, R.P. An overview of the recent developments in polylactide (PLA) research. Bioresour. Technol. 2010, 101, 8493-8501. [CrossRef]

87. Zhao, D.; Zhu, T.; Li, J.; Cui, L.; Zhang, Z.; Zhuang, X.; Ding, J. Poly(lactic-co-glycolic acid)-based composite bone-substitute materials. Bioact. Mater. 2021, 6, 346-360. [CrossRef]

88. Okada, T.; Nobunaga, Y.; Konishi, T.; Yoshioka, T.; Hayakawa, S.; Lopes, M.A.; Miyazaki, T.; Shirosaki, Y. Preparation of chitosan-hydroxyapatite composite mono-fiber using coagulation method and their mechanical properties. Carbohydr. Polym. 2017, 175, 355-360. [CrossRef]

89. Muzzarelli, R.A.A. Chitins and chitosans for the repair of wounded skin, nerve, cartilage and bone. Carbohyd. Polym. 2009, 76, 167-182. [CrossRef]

90. Athanasiou, K.A.; Niederauer, G.G.; Agrawal, C.M. Sterilization, toxicity, biocompatibility and clinical applications of polylactic acid/polyglycolic acid copolymers. Biomaterials 1996, 17, 93-102. [CrossRef]

91. Carfi, P.F.; Conoscenti, G.; Greco, S.; La Carrubba, V.; Ghersi, G.; Brucato, V. Preparation, characterization and in vitro test of composites poly-lactic acid/hydroxyapatite scaffolds for bone tissue engineering. Int. J. Biol. Macromol. 2018, 119, 945-953. [CrossRef] [PubMed]

92. Zhang, H.; Fu, Q.W.; Sun, T.W.; Chen, F.; Qi, C.; Wu, J.; Cai, Z.Y.; Qian, Q.R.; Zhu, Y.J. Amorphous calcium phosphate, hydroxyapatite and poly(d,l-lactic acid) composite nanofibers: Electrospinning preparation, mineralization and in vivo bone defect repair. Colloids Surf. B Biointerfaces 2015, 136, 27-36. [CrossRef] [PubMed]

93. Corcione, C.E.; Gervaso, F.; Scalera, F.; Padmanabhan, K.S.; Madaghiele, M.; Montagna, F.; Sannino, A.; Licciulli, A.; Maffezzoli, A. Highly loaded hydroxyapatite microsphere/ PLA porous scaffolds obtained by fused deposition modelling. Ceram. Int. 2019, 45, 2803-2810. [CrossRef]

94. Shikinami, Y.; Okuno, M. Bioresorbable devices made of forged composites of hydroxyapatite (HA) particles and poly L-lactide (PLLA). Part II: Practical properties of miniscrews and miniplates. Biomaterials 2001, 22, 3197-3211. [CrossRef]

95. Wang, X.; Song, G.; Lou, T. Fabrication and characterization of nano composite scaffold of poly(L-lactic acid)/hydroxyapatite. J. Mater. Sci. Mater. Med. 2010, 21, 183-188. [CrossRef] 
96. Smith, I.O.; Mccabe, L.R.; Baumann, M.J. MC3T3-E1 osteoblast attachment and proliferation on porous hydroxyapatite scaffolds fabricated with nanophase powder. Int. J. Nanomed. 2006, 1, 189-194. [CrossRef]

97. He, H.; Yu, J.; Cao, J.E.L.; Wang, D.; Zhang, H.; Liu, H. Biocompatibility and Osteogenic Capacity of Periodontal Ligament Stem Cells on nHAC/PLA and HA/TCP Scaffolds. J. Biomater. Sci. Polym. Ed. 2011, 22, 179-194. [CrossRef]

98. Wan, Y.; Wu, C.; Xiong, G.; Zuo, G.; Jin, J.; Ren, K.; Zhu, Y.; Wang, Z.; Luo, H. Mechanical properties and cytotoxicity of nanoplate-like hydroxyapatite/polylactide nanocomposites prepared by intercalation technique. J. Mech. Behav. Biomed. Mater. 2015, 47, 29-37. [CrossRef]

99. Webster, T.J.; Siegel, R.W.; Bizios, R. Osteoblast adhesion on nanophase ceramics. Biomaterials 1999, 20, 1221-1227. [CrossRef]

100. Wei, G.; Ma, P.X. Structure and properties of nano-hydroxyapatite/polymer composite scaffolds for bone tissue engineering. Biomaterials 2004, 25, 4749-4757. [CrossRef]

101. Kim, H.W.; Lee, H.H.; Knowles, J.C. Electrospinning biomedical nanocomposite fibers of hydroxyapatite/poly(lactic acid) for bone regeneration. J. Biomed. Mater. Res. Part A 2006, 79, 643-649. [CrossRef] [PubMed]

102. Sui, G.; Yang, X.; Mei, F.; Hu, X.; Chen, G.; Deng, X.; Ryu, S. Poly-L-lactic acid/hydroxyapatite hybrid membrane for bone tissue regeneration. J. Biomed. Mater. Res. Part A 2007, 82, 445-454. [CrossRef] [PubMed]

103. Bharadwaz, A.; Jayasuriya, A.C. Recent trends in the application of widely used natural and synthetic polymer nanocomposites in bone tissue regeneration. Mater. Sci. Eng. C-Mater. Biol. Appl. 2020, 110, 110698. [CrossRef] [PubMed]

104. Raghavendran, H.R.B.; Puvaneswary, S.; Talebian, S.; Murali, M.R.; Naveen, S.V.; Krishnamurithy, G.; McKean, R.; Kamarul, T. A comparative study on in vitro osteogenic priming potential of electron spun scaffold PLLA/HA/Col, PLLA/HA, and PLLA/Col for tissue engineering application. PLoS ONE 2014, 9, e104389. [CrossRef] [PubMed]

105. Zhang, H.; Mao, X.; Du, Z.; Jiang, W.; Han, X.; Zhao, D.; Han, D.; Li, Q. Three dimensional printed macroporous polylactic acid/hydroxyapatite composite scaffolds for promoting bone formation in a critical-size rat calvarial defect model. Sci. Technol. Adv. Mater. 2016, 17, 136-148. [CrossRef] [PubMed]

106. Liao, S.S.; Cui, F.Z.; Zhang, W.; Feng, Q.L. Hierarchically biomimetic bone scaffold materials: Nano-HA/collagen/PLA composite. J. Biomed. Mater. Res. Part B 2004, 69, 158-165. [CrossRef]

107. Norouzi, M.; Shabani, I.; Ahvaz, H.H.; Soleimani, M. PLGA/gelatin hybrid nanofibrous scaffolds encapsulating EGF for skin regeneration. J. Biomed. Mater. Res. Part A 2015, 103, 2225-2235. [CrossRef]

108. Huang, Y.C.; Connell, M.; Park, Y.; Mooney, D.J.; Rice, K.G. Fabrication and in vitro testing of polymeric delivery system for condensed DNA. J. Biomed. Mater. Res. Part A 2003, 67, 1384-1392. [CrossRef]

109. Okamoto, M.; John, B. Synthetic biopolymer nanocomposites for tissue engineering scaffolds. Prog. Polym. Sci. 2013, 38, 1487-1503. [CrossRef]

110. Danhier, F.; Ansorena, E.; Silva, J.M.; Coco, R.; Le Breton, A.; Preat, V. PLGA-based nanoparticles: An overview of biomedical applications. J. Control. Release 2012, 161, 505-522. [CrossRef]

111. Fisher, P.D.; Venugopal, G.; Milbrandt, T.A.; Hilt, J.Z.; Puleo, D.A. Hydroxyapatite-reinforced in situ forming PLGA systems for intraosseous injection. J. Biomed. Mater. Res. Part A 2015, 103, 2365-2373. [CrossRef] [PubMed]

112. Fu, C.; Bai, H.; Zhu, J.; Niu, Z.; Bai, Y. Enhanced cell proliferation and osteogenic differentiation in electrospun PLGA/hydroxyapatite nanofibre scaffolds incorporated with graphene oxide. PLoS ONE 2017, 12, e188352. [CrossRef] [PubMed]

113. Huang, Y.X.; Ren, J.; Chen, C.; Ren, T.B.; Zhou, X.Y. Preparation and Properties of Poly(lactide-co-glycolide) (PLGA)/ NanoHydroxyapatite (NHA) Scaffolds by Thermally Induced Phase Separation and Rabbit MSCs Culture on Scaffolds. J. Biomater. Appl. 2008, 22, 409-432. [CrossRef] [PubMed]

114. Petricca, S.E.; Marra, K.G.; Kumta, P.N. Chemical synthesis of poly(lactic-co-glycolic acid)/hydroxyapatite composites for orthopaedic applications. Acta Biomater. 2006, 2, 277-286. [CrossRef]

115. Cieslik, M.; Mertas, A.; Morawska-Chochol, A.; Sabat, D.; Orlicki, R.; Owczarek, A.; Krol, W.; Cieslik, T. The evaluation of the possibilities of using PLGA co-polymer and its composites with carbon fibers or hydroxyapatite in the bone tissue regeneration process in vitro and in vivo examinations. Int. J. Mol. Sci. 2009, 10, 3224-3234.

116. Kumar, M.N.V.R.; Muzzarelli, R.A.A.; Muzzarelli, C.; Sashiwa, H.; Domb, A.J. Chitosan chemistry and pharmaceutical perspectives. Chem. Rev. 2004, 104, 6017-6084. [CrossRef]

117. Kim, I.Y.; Seo, S.J.; Moon, H.S.; Yoo, M.K.; Park, I.Y.; Kim, B.C.; Cho, C.S. Chitosan and its derivatives for tissue engineering applications. Biotechnol. Adv. 2008, 26, 1-21. [CrossRef]

118. Zou, Z.; Wang, L.; Zhou, Z.; Sun, Q.; Liu, D.; Chen, Y.; Hu, H.; Cai, Y.; Lin, S.; Yu, Z.; et al. Simultaneous incorporation of PTH(1-34) and nano-hydroxyapatite into Chitosan/Alginate Hydrogels for efficient bone regeneration. Bioact. Mater. 2021, 6, 1839-1851. [CrossRef]

119. Mohammadi, Z.; Mesgar, A.S.; Rasouli-Disfani, F. Reinforcement of freeze-dried chitosan scaffolds with multiphasic calcium phosphate short fibers. J. Mech. Behav. Biomed. Mater. 2016, 61, 590-599. [CrossRef]

120. Pangon, A.; Saesoo, S.; Saengkrit, N.; Ruktanonchai, U.; Intasanta, V. Hydroxyapatite-hybridized chitosan/chitin whisker bionanocomposite fibers for bone tissue engineering applications. Carbohydr. Polym. 2016, 144, 419-427.

121. Ito, M. In vitro properties of a chitosan-bonded hydroxyapatite bone-filling paste. Biomaterials 1991, 12, 41-45. [CrossRef] 
122. Costa-Pinto, A.R.; Correlo, V.M.; Sol, P.C.; Bhattacharya, M.; Charbord, P.; Delorme, B.; Reis, R.L.; Neves, N.M. Osteogenic Differentiation of Human Bone Marrow Mesenchymal Stem Cells Seeded on Melt Based Chitosan Scaffolds for Bone Tissue Engineering Applications. Biomacromolecules 2009, 10, 2067-2073. [CrossRef] [PubMed]

123. Hu, Q.; Li, B.; Wang, M.; Shen, J. Preparation and characterization of biodegradable chitosan/hydroxyapatite nanocomposite rods via in situ hybridization: A potential material as internal fixation of bone fracture. Biomaterials 2004, 25, 779-785. [CrossRef]

124. Shahzadi, L.; Zeeshan, R.; Yar, M.; Bin Qasim, S.; Chaudhry, A.A.; Khan, A.F.; Muhammad, N. Biocompatibility Through Cell Attachment and Cell Proliferation Studies of Nylon 6/Chitosan/Ha Electrospun Mats. J. Polym. Environ. 2018, 26, 2030-2038. [CrossRef]

125. Zhao, F.; Grayson, W.L.; Ma, T.; Bunnell, B.; Lu, W.W. Effects of hydroxyapatite in 3-D chitosan-gelatin polymer network on human mesenchymal stem cell construct development. Biomaterials 2006, 27, 1859-1867. [CrossRef]

126. Dhivya, S.; Saravanan, S.; Sastry, T.P.; Selvamurugan, N. Nanohydroxyapatite-reinforced chitosan composite hydrogel for bone tissue repair in vitro and in vivo. J. Nanobiotechnol. 2015, 13, 40. [CrossRef]

127. Danilchenko, S.N.; Kalinkevich, O.V.; Pogorelov, M.V.; Kalinkevich, A.N.; Sklyar, A.M.; Kalinichenko, T.G.; Ilyashenko, V.Y.; Starikov, V.V.; Bumeyster, V.I.; Sikora, V.Z.; et al. Characterization and in vivo evaluation of chitosan-hydroxyapatite bone scaffolds made by one step coprecipitation method. J. Biomed. Mater. Res. Part A 2011, 96, 639-647. [CrossRef]

128. Zhang, X.; Zhu, L.; Lv, H.; Cao, Y.; Liu, Y.; Xu, Y.; Ye, W.; Wang, J. Repair of rabbit femoral condyle bone defects with injectable nanohydroxyapatite/chitosan composites. J. Mater. Sci. Mater. Med. 2012, 23, 1941-1949. [CrossRef]

129. Ma, X.Y.; Feng, Y.F.; Ma, Z.S.; Li, X.; Wang, J.; Wang, L.; Lei, W. The promotion of osteointegration under diabetic conditions using chitosan/hydroxyapatite composite coating on porous titanium surfaces. Biomaterials 2014, 35, 7259-7270. [CrossRef]

130. Lin, K.F.; He, S.; Song, Y.; Wang, C.M.; Gao, Y.; Li, J.Q.; Tang, P.; Wang, Z.; Bi, L.; Pei, G.X. Low-Temperature Additive Manufacturing of Biomimic Three-Dimensional Hydroxyapatite/Collagen Scaffolds for Bone Regeneration. ACS Appl. Mater. Interfaces 2016, 8, 6905-6916. [CrossRef]

131. Azami, M.; Moztarzadeh, F.; Tahriri, M. Preparation, characterization and mechanical properties of controlled porous gelatin/hydroxyapatite nanocomposite through layer solvent casting combined with freeze-drying and lamination techniques. $J$. Porous Mat. 2010, 17, 313-320. [CrossRef]

132. Eshraghi, S.; Das, S. Micromechanical finite-element modeling and experimental characterization of the compressive mechanical properties of polycaprolactone-hydroxyapatite composite scaffolds prepared by selective laser sintering for bone tissue engineering. Acta Biomater. 2012, 8, 3138-3143. [CrossRef] [PubMed]

133. Baji, A.; Wong, S.C.; Srivatsan, T.S.; Njus, G.; Mathur, G. Processing Methodologies for Polycaprolactone-Hydroxyapatite Composites: A Review. Mater. Manuf. Process. 2006, 21, 211-218. [CrossRef]

134. Supova, M. Problem of hydroxyapatite dispersion in polymer matrices: A review. J. Mater. Sci. Mater. Med. 2009, 20, 1201-1213. [CrossRef]

135. Kim, M.S.; Khang, G.; Hai, B.L. Gradient polymer surfaces for biomedical applications. Prog. Polym. Sci. 2008, 33, 138-164. [CrossRef]

136. Qiu, X.; Hong, Z.; Hu, J.; Chen, L.; Chen, X.; Jing, X. Hydroxyapatite surface modified by L-lactic acid and its subsequent grafting polymerization of L-lactide. Biomacromolecules 2005, 6, 1193-1199. [CrossRef]

137. Liu, Q.; Wijn, J.R.D.; Bakker, D.; Blitterswijk, C.A.V. Surface modification of hydroxyapatite to introduce interfacial bonding with polyactiveTM 70/30 in a biodegradable composite. J. Mater. Sci. Mater. Med. 1996, 7, 551-557. [CrossRef]

138. Liu, Q.; Wijn, J.R.D.; Bakker, D.; Toledo, M.V.; Blitterswijk, C.A.V. Polyacids as bonding agents in hydroxyapatite polyester-ether (PolyactiveTM 30/70) composites. J. Mater. Sci. Mater. Med. 1998, 9, 23-30. [CrossRef]

139. Qiu, X.; Hong, Z.; Hu, J.; Chen, L.; Chen, X.; Jing, X. Surface-modified hydroxyapatite linked byL-lactic acid oligomer in the absence of catalyst. J. Polym. Sci. Part A Polym. Chem. 2005, 43, 5177-5185. [CrossRef]

140. Hong, Z.; Qiu, X.; Sun, J.; Deng, M.; Chen, X.; Jing, X. Grafting polymerization of L-lactide on the surface of hydroxyapatite nano-crystals. Polymer 2004, 45, 6699-6706. [CrossRef]

141. Hong, Z.; Zhang, P.; He, C.; Qiu, X.; Liu, A.; Chen, L.; Chen, X.; Jing, X. Nano-composite of poly(L-lactide) and surface grafted hydroxyapatite: Mechanical properties and biocompatibility. Biomaterials 2005, 26, 6296-6304. [CrossRef] [PubMed]

142. Wei, J.; Liu, A.; Chen, L.; Zhang, P.; Chen, X.; Jing, X. The surface modification of hydroxyapatite nanoparticles by the ring opening polymerization of gamma-benzyl-l-glutamate N-carboxyanhydride. Macromol. Biosci. 2009, 9, 631-638. [CrossRef] [PubMed]

143. Liu, Y.; Cui, H.; Zhuang, X.; Zhang, P.; Cui, Y.; Wang, X.; Wei, Y.; Chen, X. Nano-hydroxyapatite Surfaces Grafted with Electroactive Aniline Tetramers for Bone-Tissue Engineering. Macromol. Biosci. 2013, 13, 356-365. [CrossRef] [PubMed]

144. Azzaoui, K. Novel Tricomponenets composites Films from Polylactic Acid/ Hydroxyapatite/ Poly-Caprolactone Suitable For Biomedical Applications. J. Mater. Environ. Sci. 2016, 7, 761-769.

145. Shuai, C.; Yu, L.; Yang, W.; Peng, S.; Feng, P. Phosphonic Acid Coupling Agent Modification of HAP Nanoparticles: Interfacial Effects in PLLA/HAP Bone Scaffold. Polymers 2020, 12, 199. [CrossRef]

146. Shao, N.; Guo, J.; Guan, Y.; Zhang, H.; Li, X.; Chen, X.; Zhou, D.; Huang, Y. Development of organic/inorganic compatible and sustainably bioactive composites for effective bone regeneration. Biomacromolecules 2018, 19, 3637-3648. [CrossRef]

147. Zhang, P.; Hong, Z.; Yu, T.; Chen, X.; Jing, X. In vivo mineralization and osteogenesis of nanocomposite scaffold of poly(lactideco-glycolide) and hydroxyapatite surface-grafted with poly(L-lactide). Biomaterials 2009, 30, 58-70. [CrossRef] 
148. Cui, Y.; Liu, Y.; Cui, Y.; Jing, X.; Zhang, P.; Chen, X. The nanocomposite scaffold of poly(lactide-co-glycolide) and hydroxyapatite surface-grafted with 1-lactic acid oligomer for bone repair. Acta Biomater. 2009, 5, 2680-2692. [CrossRef]

149. Song, X.; Ling, F.; Ma, L.; Yang, C.; Chen, X. Electrospun hydroxyapatite grafted poly(L-lactide)/poly(lactic-co-glycolic acid) nanofibers for guided bone regeneration membrane. Compos. Sci. Technol. 2013, 79, 8-14. [CrossRef]

150. Liao, L.; Yang, S.; Miron, R.J.; Wei, J.; Zhang, Y.; Zhang, M. Osteogenic properties of PBLG-g-HA/PLLA nanocomposites. PLoS ONE 2014, 9, e105876. [CrossRef] 